\title{
Discussion on the Special Lithosphere Type in Eastern China
}

\author{
Wan Tianfeng, Zhao Qingle, Lu Haifeng, Wang Qianqian, Sun Changbin \\ School of Earth Sciences and Resources, China University of Geosciences, Beijing, China
}

Email address:

wan-tianfeng@163.com (Wan Tianfeng)

To cite this article:

Wan Tianfeng, Zhao Qingle, Lu Haifeng, Wang Qianqian, Sun Changbin. Discussion on the Special Lithosphere Type in Eastern China. Earth Sciences. Vol. 5, No. 1, 2016, pp. 1-12. doi: 10.11648/j.earth.20160501.11

\begin{abstract}
In this paper, the authors proposed that there is a special type of thin lithosphere, with continental crust (about $35 \mathrm{~km}$ thick) and oceanic mantle (about $40 \mathrm{~km}$ thick) in eastern China. The characteristics of eastern China lithosphere is so special, it is different to most of continental lithosphere of globe. To detail research the characteristics and evolution of eastern Asian lithosphere is important, which will be helpful to develop the theory of global plate tectonics. This paper will expound the thickness change, tectonic characteristics and transformation period of lithosphere type, and to discuss its mechanism.
\end{abstract}

Keywords: Lithosphere Type Transformation, Continental Crust and Oceanic Mantle Type, Counterclockwise Rotation of Continental Crust, Mechanism

\section{Introduction}

In the recent geological research of China, the most of researchers always recognized that the Eastern China block is not the typical platform or orogenic belt, but also nor the typical continental lithosphere plate or collision zone. The characteristics of Eastern China blocks were formed the uniform crystallization basement respectively that of Sino-Korean Plate was in the end of Paleoproterozoic, Yangtze Plate in the Neoproterozoic and Cathaysian Plate in the end of Early Paleozoic [1]. Those blocks became to the typical stable plates before the end of Paleozoic, however, they occurred the strong tectono-magmatism since Jurassic. Thus, based on the characteristics of tectonic unit, the Eastern China block had been named by many famous researchers, for example, be called active or para-platform [2-5], active continental margin [6-8], folding zone in platform [9-10], intraplate orogenic belt or intracontinental orogenic zone [11-15]. In recent, the many researches study "the destruction of North China Craton" profitably [16-22].

The proposals of those tectonic terms all had some foundations and reasons. However, due to rare the data of deep geology, geochemistry and geophysics, many geological phenomena are understood, and it did not knew the reason in past sixty years, thus had evoked a lot of controversy and proposed many hypotheses.

The special lithosphere tectonic was first recognized by
Melcher et al. [23], they discovered that the continental crust could be thrusting and moved onto the oceanic mantle between the Europe and African continents during the Paleogene, and called that mantle is a "pre-oceanic subcontinent mantle", their results greatly inspired the authors.

This paper will expound the thickness change, tectonic characteristics and transformation period of lithosphere type, and to discuss its mechanism. In view of that above problems are the discussion hotspot of earth scientific society, the authors just proposed their own opinion for discussion.

\section{The Thickness Change of Eastern China Lithosphere}

As to existed thinner lithosphere in Eastern China, using the seismic tomography, Xin Jisan et al. (Institute of Geophysics and Geochemistry, Bureau of Shanxi Geology and Exploration) first discovered that the lithosphere thickness is obviously thinner (to about $80 \mathrm{~km}$ ) east to Taihang Mountains (unpublished paper), after that their map was quoted by many researchers. Fan and Menzies [24] first published the paper and pointed out clearly that based on the formation depth of kimberlite, the thickness of lithosphere was about $200 \mathrm{~km}$ during the Paleozoic and former periods, and that thinned out to $120 \mathrm{~km}$ since Mesozoic, quoted some unpublished papers. Later, the above conclusion was confirmed by original formation depth of a lot of mantle source xenoliths, and also verified by 
the data of two-pyroxene geothermo-barometer and more geophysical exploration results [25-29] (Fig. 1 and 2).

In Fig. 2, Wan and Wang [28] drown the border between eastern strong magmatic area and western weak magmatic area (Fault No.13, in Fig. 2). Some petrologists called that to be "magmatic line" in China (Xue H M personal communication, 2011). It located through western Okhotsk Sea, across west to Dahingganling, the border between China and Mongolia, middle Shanxi, western Hubei, western Hunan, towards eastern Yunnan, even southwestwards to western Thailand, from north to south, which is the west border of Eastern China thin lithosphere. In the area east to above border, the lithosphere thickness is about 70-80 km mostly, only at the Wuhan and its surrounding area is thicker, reached $90 \mathrm{~km}$ or more. In the area, west to above border, the continental lithosphere thicknesses are all 100-180 km, belong to normal continental lithosphere (thicknesses of crust are 40-60 km and of lithosphere mantle are $60-120 \mathrm{~km} \mathrm{[1]),} \mathrm{which} \mathrm{is} \mathrm{the} \mathrm{main}$ part of China continental lithosphere (Fig. 1). The border of thickness change of Eastern China lithosphere is located west to recent gravity anomaly gradient zone [30], both locations are rather nearly.

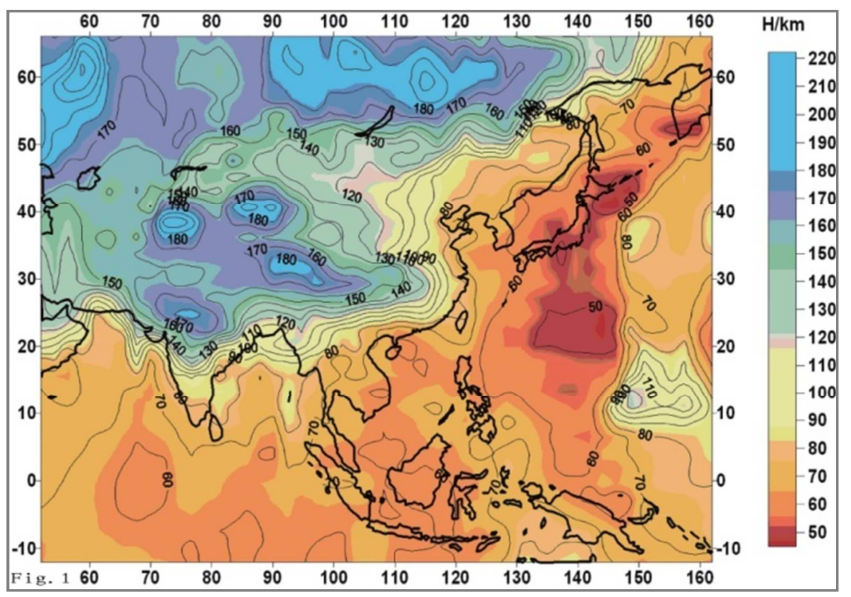

Fig. 1. The lithosphere thickness of Eastern Asia-Western Pacific Ocean (Based on the $S$ wave seismic tomography, [26, 29].

The recent east border of Eastern China thin lithosphere is the trench-subduction zone among the Asian Continent, Pacific Ocean and Philippine Sea Plates (No.14, in Fig. 2). Thus, the eastern China thin lithosphere could be called "Eastern Asian thin lithosphere", which maybe includes the Eastern China, Far East of Russia, Korean Peninsula, most of Indosinian Peninsula, Japan Islands, Philippine Islands, Indonesia (Sunda) Islands and their surrounding seas. The thickness of Eastern Asian thin lithosphere is about 70-80 km at continental region, however is generally $70-60 \mathrm{~km}$ beneath islands and sea areas. Only nearest to recent subduction zone, the thickness of continental crust in the arc island zone has a little bit thickened, influenced by subduction, roll-back and compression. The thicknesses of lithosphere in Pacific and Philippine Sea Plates are less than $60 \mathrm{~km}$, usually about 50-60 $\mathrm{km}$, included the thickness of oceanic crust is less than $10 \mathrm{~km}$ and of oceanic lithosphere mantle is often $40-50 \mathrm{~km}$, they are belong to normal oceanic lithosphere [1].

East to Dahingganling - middle Shanxi - western Hubei western Hunan -Eastern Yunnan, the tectono-magmatism was rather strong in Jurassic-Early epoch of Early Cretaceous (200 - $135 \mathrm{Ma})$, i. e. be called the Yanshanian Tectonic Period [31-33] The distribution area of magmatic rocks, formed in Yanshanian Tectonic Period, is more than $229000 \mathrm{~km}^{2}$, i. e. about $25 \%$ of magma rock outcrop area in whole China [34], which is the strongest tectono-magmatism in Eastern China.

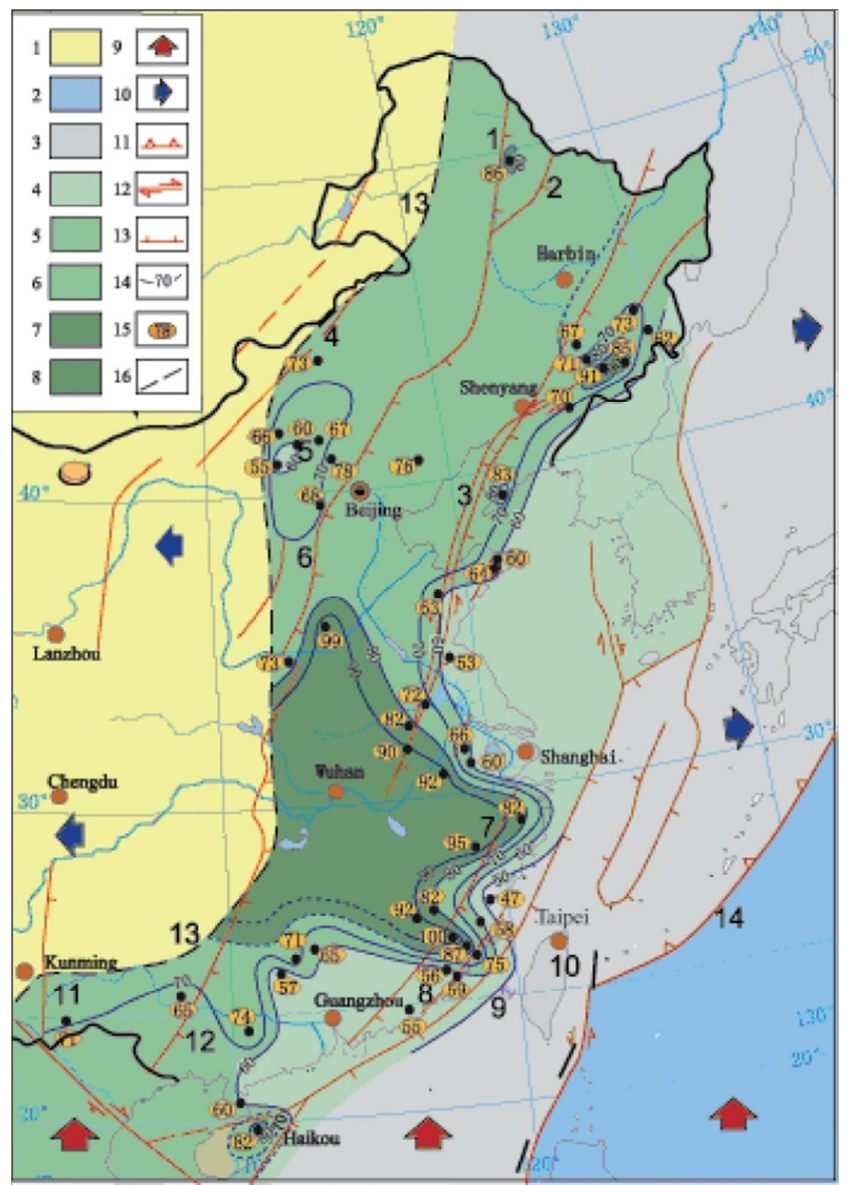

Fig. 2. The lithosphere thickness during Himalayan Period $(23-0.78 \mathrm{Ma})$ in Eastern China [28].

Legend: 1. Continental crust area with weak magmatism; 2. Oceanic crust area; 3-8. Continental crust with strong magmatism, lithosphere thickness is respectively: $3 .(<50 \mathrm{~km}), 4 .(50-60 \mathrm{~km}), 5 .(60-70 \mathrm{~km}), 6 .(70-80 \mathrm{~km})$, 7. $(80-90 \mathrm{~km}) ; 8 .(>90 \mathrm{~km})$; 9. Compression direction; 10. Extension direction; 11. Subduction zone; 12. Strike-slip fault; 13. Normal fault; 14. Isobaths of lithosphere bottom; 15. Inferred depth of data point of lithosphere bottom, estimated by original formation depth of mantle xenoliths; 16 . The border between weak and strong magmatism areas.

Fault number: 1. northern section of East Dahingganling fault; 2. Xiaohingganling fault; 3. Tancheng-Lujiang lithosphere fault zone; 4. Xilin Gol fault; 5. Zhangbei-Datong fault; 6. east border of Taihang Mountians fault; 7. middle part of Zhejiang and Fujian (Xinchang-Mingxi) fault zone; 8. Longhai-Santou fault; 9. Penhu fault; 10. East and North Taiwan fault zone; 11. Southeast Yunnan fault; 12. Southern Guangxi fault and Leizhou Peninsula-Wenchang hidden fault; 13. border between weak and strong magmatic areas, i. e. west border of Eastern Asia thin lithosphere; 14. Subduction zone between continental and oceanic crust, i. e. east border of Eastern Asia thin lithosphere. 
A series of NE-NNE trending faults, controlled by WNW trending maximum principal compression stress, caused a partial decrease in pressure and increase in temperature in the crust, especially at the intersections among the faults and middle crust or the Mohorovicic discontinuity. The magmatism mainly originated in the middle crust and near the Mohorovicic discontinuity [28], mostly belong to the calcalkaline series rocks. Thus the intermediate and acid composition silicic intrusions and volcanic rocks mainly formed along the faults in the crust. In the Yanshanian Period, there are many $\mathrm{S}$ types granitic magma intruded along low angle thrusts, caused the intrusion bodies with extension distribution [1, 28, 34, 35]. According to the statistic limb attitudes of fold [1] the crust horizontal shortening rates, with near ESE-WNW trending in Eastern China thin lithosphere during Yanshanian Period, are between 11\% and $23.4 \%$, which could be caused the crust thickened, increase about $4-8 \mathrm{~km}[1]$.

In the Middle epoch of Early Cretaceous-Paleocene (135$52 \mathrm{Ma}$ ), it could be called Late Yanshanian Period in the former, but Li C Y [36] was first named this period to call the Sichuanian Tectonic Period, the magmatism was also rather stronger, but the magmatism distribution area of Cretaceous is much less than that of Jurassic, only $43864 \mathrm{~km}^{2}$, about $5 \%$ of the magmatic rock outcrop area in whole China, which is the one fifth of magmatic rock outcrop area of Jurassic [34]. If considered the Cretaceous magmatism underneath sedimentary basins, the magmatic rock outcrop area will be bigger.

Outcrops of magmatic rocks of the Sichuanian Period are arranged in linear patterns or as scattered intrusions, very different from the distribution of S-type granites in the Yanshanian Period. Although the magmatic rocks belong to the calc-alkaline series, with a high $\mathrm{SiO}_{2}$ content (average $71.43 \%$ ), a high alkali content (8.45\%) and lower total mafic content $(3.15 \%)$, magmatic activity in the Sichuanian Period had its own individual character [34]. Magmatic rocks intruded during the Sichuanian Period in Eastern China lithosphere are distributed mainly along three NNE trending transtensional fault belts, there are the Dahingganling-Taihang Mountians (Fault No. 1, 6 and 12, in Fig. 2), the Tancheng-Lujiang Fault Zone (Fault No.3, in Fig. 2) and the coastal zone of southeast China (Lishui-Dapu-Lianhuashan and the ChangleNan'ao zones; Fault No.8 and 9, in Fig. 2). The main granitic rocks are A-types, where the original source magma formed at the intersection zone of NNE trending faults and the Mohorovìì discontinuity; less than one third of the intrusions are S-type, with a source of the original magma in the crust, often caused at the intersection of NNE trending faults and low velocity layer of middle crust; and while only a few basaltic dykes or ultrabasic xenoliths inclusions had a deep source, originated at the base of the lithosphere. The formation of original source magma was usually located near the intersection zone among NNE trending extensional faults and the Mohorovìcic discontinuity or middle crust; it is suggested that magmas originated at local detachment or fracturing parts at those levels [1, 28, 37].

Due to the most of magmatism during Jurassic and
Cretaceous in Eastern China lithosphere are originated in near the Mohorovìcic discontinuity or middle crust, it is a little bit difficult to use the characteristics of magmatic rock to infer deep feature of mantle. However, since Late Cretaceous, some basic rocks and their xenoliths intruded into lithosphere faults, which will be helpful to deduce the geochemistry characteristics for deep part of lithosphere.

\section{Transformation Period of Lithosphere Type}

The transformation period of lithosphere type of Eastern Asian, especially that of North China, is discussed very often in recent. As to the peridotite xenoliths in kimberlite formed in North China during Ordovician, in former used the depleted degree of major element in lithosphere mantle, i. e. the forsterite composition (Fo), inferred that the formation age of lithosphere mantle is Archean, in which Fo is more than 92. Later, measured the more accurate Os-Re isotopic for those rocks, it is discovered that the magmatic depleted model ages of those are also mainly in the Archean. Comparing the calculated results of mineral geothermo-barometer, Lu et al. [3840], Zhou [41] and Zhang [42] recognized that the lithosphere thicknesses of Eastern China are about 200-220 km from Archaean to Triassic (Fig. 3). The Eastern China blocks migrated continuously in Paleo-Tethys Ocean during Paleozoic and collided to Siberian and Mongolian Tectonic Domains in Middle Permian and Triassic, the intraplate deformation was very weak, and converged to northward gradually $[1,43]$.

Zhou X H [44] considered that the late epoch of Jurassic (160-140 Ma) is the key transformation period of lithosphere type in North China. The crust thickness (from blue-purple to white, in Fig.3) changed a little, but the thickness of lithosphere mantle (blue in Fig. 3) changed from more than $100 \mathrm{~km}$ to $40-50 \mathrm{~km}$ suddenly, and the mantle metasomatic layer reduced to a little. His recognition and the field tectonic research [1, 35] are really identical. He pointed out that the thinning of crust and lithosphere mantle occurred in different periods and degrees. The thickness of lithosphere mantle changed suddenly in Jurassic Period, from more than $100 \mathrm{~km}$ to about $50 \mathrm{~km}$, but the thickness of crust only changed a little in that period [44]. Since the late epoch of Early Cretaceous (120 Ma) to Recent, the lithosphere thickness could be changed a little, the thickness is always keep to about 70-80 km (Fig. 1 and 2).

Influenced by about NNE trending shortening and derived near east-west trending extension during the middle epoch of Early Cretaceous - Paleocene (135-52Ma), many former NNE NE trending reverse faults or thrusts transformed to normal faults (with strike-slip) and formed a lot of basins initially in Eastern China. According to available east-west trending extension rate of normal faults and basins [1, 34, 45], the average horizontal extension rates of Eastern China are between $20 \%-30 \%$ during above period. It could be caused the crust thinner, such as decreased from $40-50 \mathrm{~km}$ to $30-40 \mathrm{~km}$. 
As to the Eocene - Oligocene (52-23 Ma), influenced by westward subduction and compression of Pacific Ocean Plate, the Eastern China lithosphere suffered the weaker and near E-W trending compression, the crust shortening rates are between $0.58 \%-2 \%$ in the most of areas, those in some of South China areas can reach to $13 \%$ - 19\% [1], thus the crust could be thickened a few kilometers. During the MioceneEarly Pleistocene (23 - $0.78 \mathrm{Ma})$, the Eastern China was suffered again the influence of N-S trending shortening, the shortening rates are between $0.56 \%-1.77 \%$. Since Middle
Pleistocene $(0.78-0 \mathrm{Ma})$ the horizontal shortening rate and thickness thicken changed only a very small [1]. Thus, it can be understood that the crust thickening and thin out in Eastern Asia since Cenozoic are rather limited, and could be to say that the crust is not thin out continuously after the Cretaceous.

As to the thickness of lithosphere mantle in Eastern Asia, compared with the data of geochemistry (Fig. 3), geophysics (Fig. 1) and original formation depth of mantle xenoliths (Fig. 2), it is almost no change, kept between 40 and $50 \mathrm{~km}$ continuously since Jurassic [1].

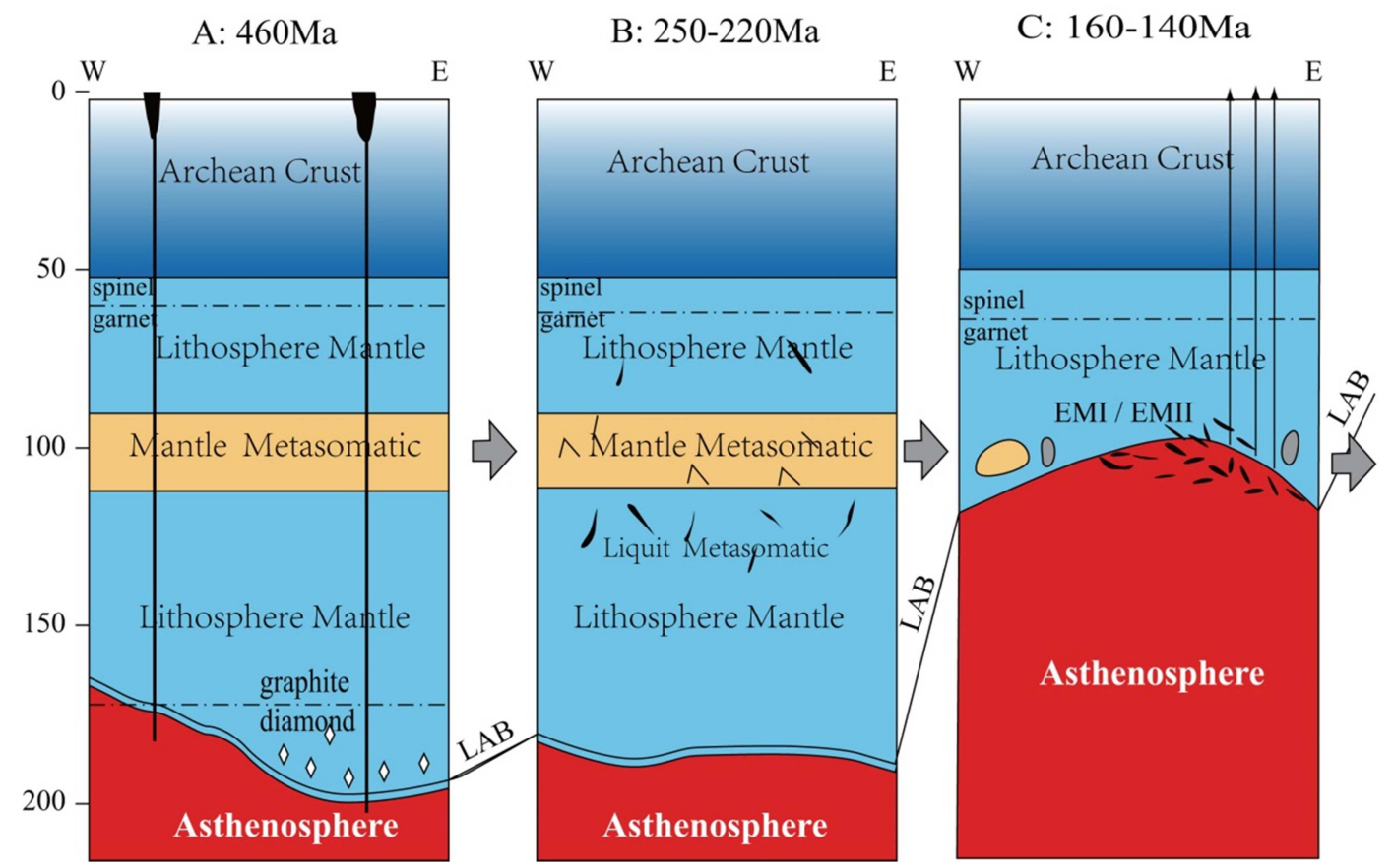

Fig. 3. The evolution model of North China continental lithosphere from Paleozoic to Jurassic [44].

In recent years, some petrology and geochemistry researchers $[39,44,46-50]$ overemphasized or only recognized that the Cretaceous magmatism is strongest in Eastern China during Mesozoic and a major period for the destruction of North China Craton, or considered that the hot mantle was uplifted and the lithosphere had thinner continuously since Cretaceous. It seems that the above hypotheses have unconfirmed by real data, due to they did not known the detail regional geological data. If the hypothesis of hot mantle uplift to cause lithosphere thin out could be formed, the crust and lithosphere mantle should be thinned out in same time and in similar degree, but the facts are that the lithosphere mantle of eastern China thin out from about $100 \mathrm{~km}$ thinner to $40-50 \mathrm{~km}$ during Late Jurassic, and the crust of that only thin out a little, from about $40 \mathrm{~km}$ to more than $30 \mathrm{~km}$ since Creta- ceous.

Should be attention to, there are many basins in the Eastern China, especially the central areas of lithosphere thinning out, i. e. Northeast and North China. The obvious characteristics of basin is that there are lower landscape and deposited thicker and low density sediments and sedimentary rocks, however the basin has always normal and high gravity anomaly. This phenomenon was explained by the uplift of Mohorovìcìc discontinuity with higher density layer in some former researchers. In recent, whether at North China, or at South China Sea [51, 52], the deep seismic exploration results showed that the dip angle of Mohorovìcìc discontinuity are all rather small, only about $2^{\circ}-3^{\circ}$, with wide wave type (Fig. 4), and it never found any obvious mantle uplift. In addition, if there is a uplift of hot mantle with lower density in the lithosphere depth really, how to cause the normal and high gravity anomaly at basin areas? The authors inferred that the high gravity anomaly was caused by intrusion bodies beneath Mohorovìcìc discontinuity before the basin formation.

\section{Oceanic Lower Crust and Mantle in Lithosphere}

In the petrology and geochemistry research of Eastern China, an important result should be attention to, many researchers $[35,38,42,50,53]$ recognized that there are the oceanic lower crust or oceanic mantle in lithosphere since Jurassic, caused basalt magma original area, according to the data of magma original depth and characteristics of chemistry composition. 


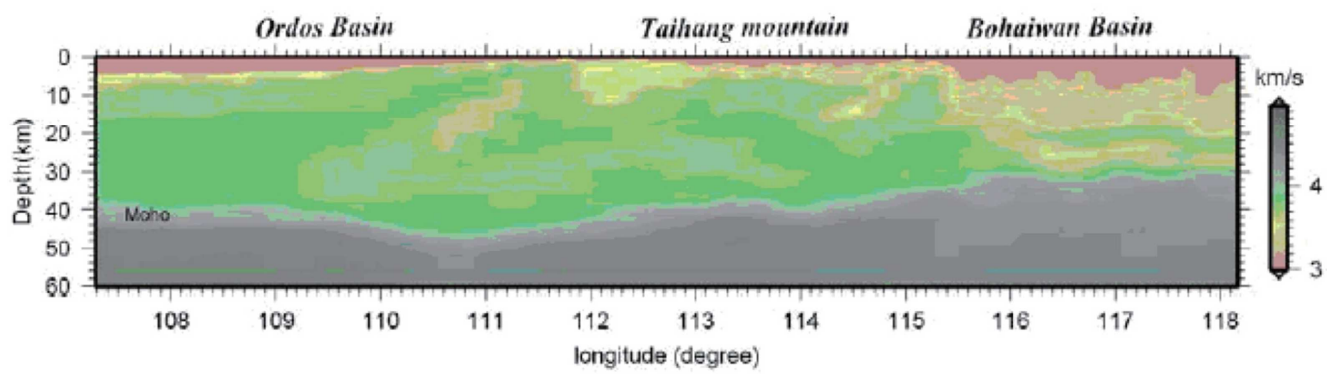

Fig. 4. S wave velocity structure of crust based on E-W trending seismic observation section in North China [51].

The value of $\mathrm{S}$ wave velocity $(\mathrm{km} / \mathrm{s})$ showed on right color column. The depth of Mohorovìcic discontinuity in figure is from about $40 \mathrm{~km}$ at western, i. e. left side - Ordos Basin; to about $30 \mathrm{~km}$ at eastern, i. e. right side, which shows to eastward a little bit uplift and wide wave type. It shows that there is no mantle uplift underneath the basin (east to $115^{\circ} \mathrm{E}$ ). The Mohorovìic discontinuity shows the clear uplift toward east, the dip angle is about $10^{\circ}$. However, due to the vertical scale of this figure is enlarged more than four times. If used same vertical and horizontal scale to make this figure, the dip angle should be rather small, only about $2^{\circ}-3^{\circ}$. In addition, it must be paid attention to that there are two low velocity zones (brown) with west inclination and intermediate dip angle in the crust at west to $111.5^{\circ} \mathrm{E}$ (middle Shanxi) and $115.4^{\circ} \mathrm{E}$ (middle Hebei), they could be the exhibition of crust faults (may be ancient collision zone) in North China block, formed in the end period of Paleoproterozoic. The west collision zone on the figure penetrate to the bottom of crust, but the east collision zone only penetrate to upper crust, which deep and low velocity could be dislocated. The authors inferred which may be caused by that the migration velocity of upper crust is faster than that of lower crust.

As to the research of basalt for North China since Middle Cretaceous (100 Ma) [49, 50, 53], it was discovered that there are three compositions for the original source: (1) Originated gabbro depleted component caused in lower part of oceanic crust $\left(\varepsilon_{\mathrm{Nd}}>7,{ }^{87} \mathrm{Sr} /{ }^{86} \mathrm{Sr}<0.7030, \mathrm{Eu} / \mathrm{Eu}^{*}>1.2\right)$; (2) Originated enrichment component within metamorphic basalt and some sediments $\left(\varepsilon_{\mathrm{Nd}} \sim 3,{ }^{87} \mathrm{Sr} /{ }^{86} \mathrm{Sr}>0.7030, \mathrm{Eu} / \mathrm{Eu}^{*} \sim 1\right)$; (3) Surrounding mantle, but this component is relative rare. It is explained obviously that some oceanic crusts participate in basalt origination partially by above data.

Depending on the data of ratio of Eu/Eu* and ${ }^{87} \mathrm{Sr} /{ }^{86} \mathrm{Sr}$ changing tendency followed with time (Fig. 5), Xu et al.[50] considered that the basalt source area suffered the transformation progress from upper oceanic crust to lower oceanic crust since Middle Cretaceous, i. e. the depth of source areas were going to deeper. It is identical basically to the recognition of that depth of magma source areas are going to deeper in Eastern China since Cretaceous [28, 37, 53].

When it recognized that oceanic crust or oceanic lithosphere mantle could be existed in lower part of lithosphere for Eastern China, the important question is: are they subducted or moved to underneath China continent accompany with oceanic plate, or these oceanic crust and lithosphere mantle mainly exist in situ, never occurred great migration or disturbance?

The results of deep mantle source xenoliths researched by petrologists and geochemists [38-42, 54] discovered that lithosphere mantle and asthenosphere of Eastern China are no disturbance or a little bit disturbance, and many times of weak disturbances all occurred in Archaean $(>3.8 \mathrm{Ga}, 2.5 \mathrm{Ga})$ and Proterozoic (1.4 - 1.3Ga, $0.9-0.7 \mathrm{Ga})$, till now no one could found any evidences of great disturbance of lithosphere mantle formed in Mesozoic and Cenozoic with strong disturbance.

If occurred the hot mantle uplift really, caused the lithosphere thinning, delamination on the bottom of lithosphere and occurred strong tectono-magmatism in the Meso-Cenozoic, the strong disturbance of lithosphere mantle for Eastern China should be discovered and its isotopic ages should be measured during Mesozoic-Cenozoic. However, the existing data do not support the hypotheses of Meso-Cenozoic mantle uplift.

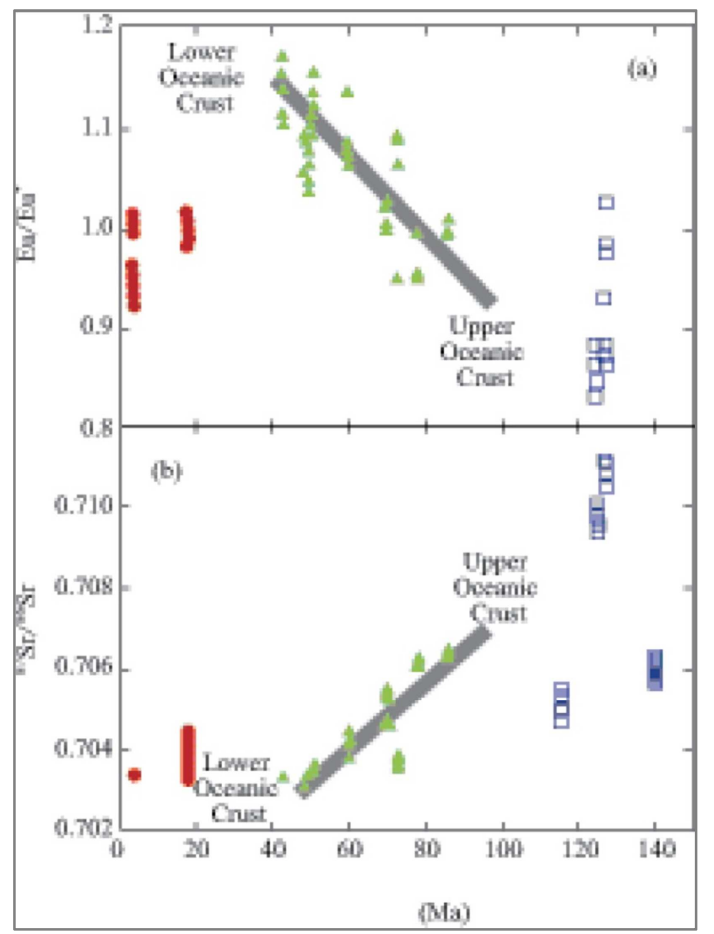

Fig. 5. The ratio of Eu/Eu* and $87 \mathrm{Sr} / 86 \mathrm{Sr}$ changing tendency followed with time, for the basalts $(\mathrm{MgO}>8 \mathrm{wt} \%)$ of North and Northeast China areas during 100-40 Ma [50].

If the Eastern China lithosphere thinning connected with oceanic plate subduction, the strong disturbance in lithosphere mantle for Eastern China since Jurassic should be discovered, but there are also no evidences at all. Even more, the results of geophysical data showed that the subducting oceanic plate 
since Mesozoic was underneath to Eastern China continent 500-600 km depth [51, 55, 56] (Fig. 6), but not less than 400 $\mathrm{km}$ depth. If the subduction plate had occurred a little bit rise or fall $[52,57,58]$, how to make influences with the shallow (less than $100 \mathrm{~km}$ ) lithosphere tectonics and occurred strong tectono-magmatism in crust $[28,35,43]$ ?

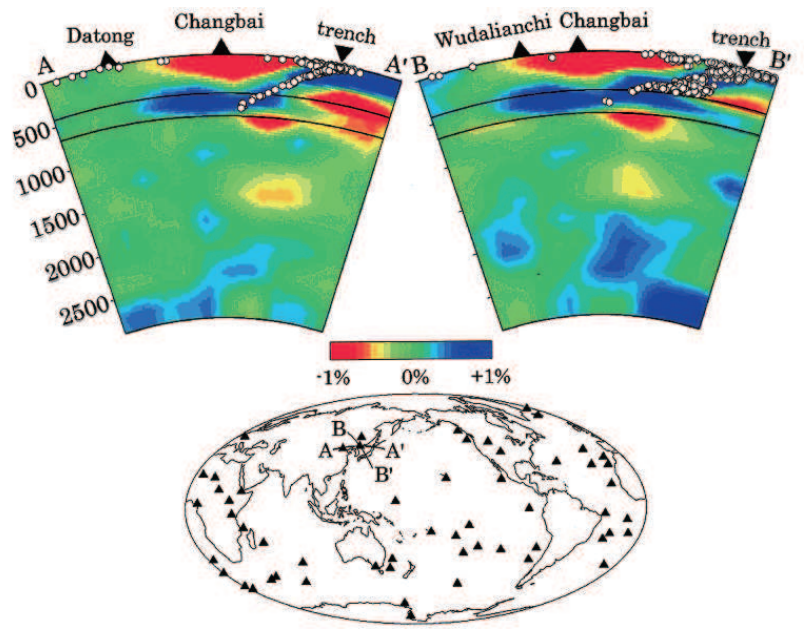

Fig. 6. Distribution of subduction zone for Eastern China and Western Pacific Ocean $[55,56]$

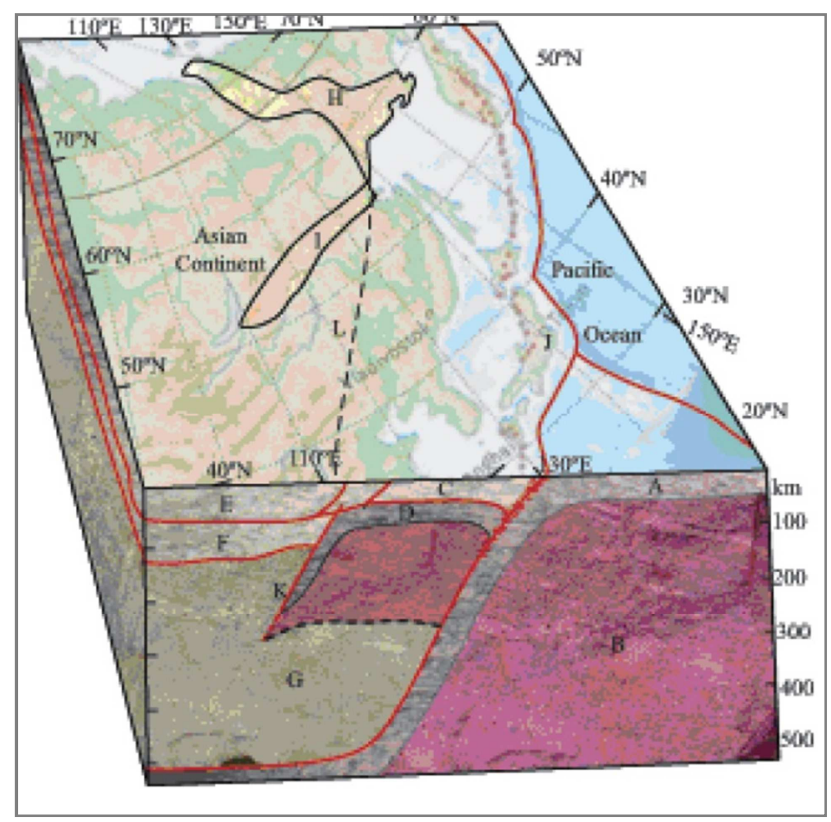

Fig. 7. The lithosphere tectonic model of Eastern Asia.

A, oceanic lithosphere (40-50km thickness); B, upper and middle mantle, beneath oceanic lithosphere; $\mathrm{C}$, a little bit thinning continental crust in Eastern Asia; D, paleo-oceanic lithosphere mantle in Eastern Asia (included some oceanic crust); E, normal continental crust in Asia; F, normal continental lithosphere mantle in Asia; G, upper and middle mantle, beneath continental lithosphere, with a little bit disturbance; H, Verkhojansk - Chersky Jurassic (200-135 Ma) Collision Accretion Zone: I, Transbaikalia (or Mongolia-Okhotsk) Jurassic (about 140Ma) Collision Accretion Zone; J, Japan island arc; $\mathrm{K}$, inferred paleo-subduction zone, between paleo-continent and paleo-ocean in mantle; L, surface border of Eastern Asia between thin lithosphere (with continental crust and oceanic lithosphere mantle) and normal continental lithosphere.
Thus, the authors considered that the oceanic crust and lithosphere mantle in Eastern China are rather stable in tectonically, they are old one, never found any evidences of great migration or strong disturbance since Jurassic. According to the comprehensive study, the authors compiled the lithosphere tectonic model of Eastern Asia (Fig. 7), and recognized that there is a thin lithosphere with continental crust and oceanic lithosphere mantle, in which the Eastern Asian continental crust (Fig. 7, C) occurred the counter clockwise rotation in Jurassic and let the partial Eastern China continental crust migrated to eastward about several hundred kilometers, caused some Eastern Asian continental crust covered onto paleo-oceanic lithosphere mantle (Fig. 7, D). The detachments occurred obviously on the Mohorovìcic discontinuity and middle crust. Thus, the special and thinner lithosphere (about 70-80 km thickness mainly) with continental crust and oceanic lithosphere mantle at Eastern Asia was formed. The authors inferred that beneath the zone of thickness changing for Eastern Asian lithosphere (along west to the Dahingganling, middle Shanxi, western Hubei, western Hunan, eastern Yunnan, toward to western Thailand), maybe there is a paleo-subduction zone between continental and oceanic lithosphere during the end of Paleoproterozoic in the depth, due to the paleo-subduction zone penetrated whole crust (Fig. 4 and 7, K).

\section{Discussion on the Mechanism of Lithosphere Transformation}

In view of many new data and discussion on geology, geochemistry and geophysics, the hypotheses of hot mantle uplift, caused the lithosphere thinning [26, 29, 38, 39, 47] and some oceanic plates (such as Pacific Ocean Plate) subduction to occur continental lithosphere thinning [17, 18, 46, 57] met hardly to overcome contradictions. In this paper, the authors proposed the recognition of lithosphere type transformation of Eastern China for colleague discussion.

The authors recognized that there was a common continental lithosphere in Eastern China before Jurassic, however that lithosphere changed to the continental crust and oceanic mantle type since Jurassic, it is based on the following data and considerations.

The first author and Zhu H. studied the paleo-magnetism since Early Paleozoic for the China and Eastern Asia areas systematically $[1,43]$ and discovered that the paleo-magnetic data are very useful, although the used results, measured by different researchers. It showed that the positions of virtual geomagnetic poles among the Chinese continental blocks from Paleozoic to Triassic had many differences and changed a lot. The Triassic was the main convergence and collision period between Sino-Korea and Yangtze Plates, which is also confirmed by the data of geology and isotopic dating [59-68], although the virtual geomagnetic poles of plates are not completely coincidentally [43, 69-73], which may be caused by further migration and deformation after collision.

In the Sino-Korean Plate, the mean paleomagnetic declina- 
tions are between $\mathrm{NW} 319^{\circ}$ and $\mathrm{NW} 338^{\circ}$ during and before Triassic [69-71, 73]; NE30 $0^{\circ}$ during the end of Late Triassic; NE $0.9^{\circ}$ for the Early Jurassic, and NE3. $6^{\circ}$ for Middle Jurassic, which are very nearly to that of recent since Jurassic [1, 43, 71, 74]. The above change could be shown on Fig. 8 (compare with Fig. 8, A and B). From Cretaceous to Quaternary, the changes of mean paleomagnetic declinations were rather small for Sino-Korean Plate and Eastern Asia areas, the declinations were all less than $8^{\circ}$, and only a few data declined bigger [70]. According to above data, it can be made clearly that the mean paleomagnetic declinations of Sino-Korean Plate during Jurassic rotated from NE30 $0^{\circ}$ to almost $\mathrm{N} 0^{\circ}$, it means that plate rotated counterclockwise about $30^{\circ}$ (Fig. 8). In other blocks of Eastern Asia there are found the evidences of counterclockwise rotation in Jurassic, it was counterclockwise rotation $20^{\circ}$ in southern Korean Peninsula [75] and in Yangtze block [76-79] during Late Triassic to Late Jurassic. The mean paleomagnetic declinations of Siberian area changed from NE $77.3^{\circ}$ to NE41.1 ${ }^{\circ}$, occurred counterclockwise rotation of $36.2^{\circ}$ [80]. In the Western China area, the locations of Junggar and Tarim blocks are obviously moved to southward $5^{\circ}-6^{\circ}$ latitude [1], which is also the exhibition of counterclockwise rotation for Eastern Asian continent.

The above data explain that the key period of mean paleo-magnetic declinations changed during Jurassic, and occurring obvious counterclockwise rotation for many blocks in Eastern Asian continent after the regional collision (Fig. 8).

Except the paleo-magnetic data, there are many important geological evidences of rotation and migration for Eastern China continent. Thus, it will discuss the distribution and migration of tectono-magmatism zone.

The volcanic rocks are widespread across the whole Northeast China. In the east side of Northeast China they are mainly intermediate-basic volcanic rocks bounded by the Dunhua-Mishan and Yanbian-Suifenhe faults, erupted in Early Jurassic (upper $J_{1}$ in Fig. 9), Laoyeling and the Yilan-Yitong faults (upper $J_{2}$ in Fig. 9) were erupted during the Middle Jurassic (171Ma-191Ma) [81]. From the basin of Songhuajiang-Nengjiang (underneath the Daqing oil field) and Dahingganling, i. e. in the middle part of Northeast China, the volcanism was mainly occurred in the Late Jurassic-Early Cretaceous (about 160-120 Ma, upper $\mathrm{J}_{3}$ in Fig. 9; Lei M S, 2012, personal communication). The migration of volcanic zone was to westwards, i. e. counter clockwise rotation. The granitoids were commonly intruded later, in the Middle to Late Jurassic (160-135 Ma), however the distribution of granitoid zones were not shown westward migration clearly in Northeast China.

The Jurassic granites in South China showed obvious zoning. Zhan M G [82] synthesised earlier studies to show that during Jurassic granitic intrusions migrated gradually eastward, volcanic zones also migrated similar granites zone (lower of Fig. 9). Early Jurassic S-type granites are located mainly in central and south-western Jiangxi (lower $\mathrm{J}_{1}$ in Fig. 9), Middle Jurassic granites extend mainly to the east of Jiangxi (lower $J_{2}$ in Fig. 9), Late Jurassic granites occurred to the west of Zhejiang, west Fujian and east Guangdong (lower $\mathrm{J}_{3}$ in Fig. 9). In Jurassic, the granite zone migrated continuously eastward about $180 \mathrm{~km}$, the average migration velocity is $0.26 \mathrm{~cm} / \mathrm{yr}$. In the above data, the granitoids are all formed in the middle crust (low seismic velocity and high conductivity) or near Mohorovìcìc discontinuity [84] and influenced by counter clockwise rotation of continental crust.
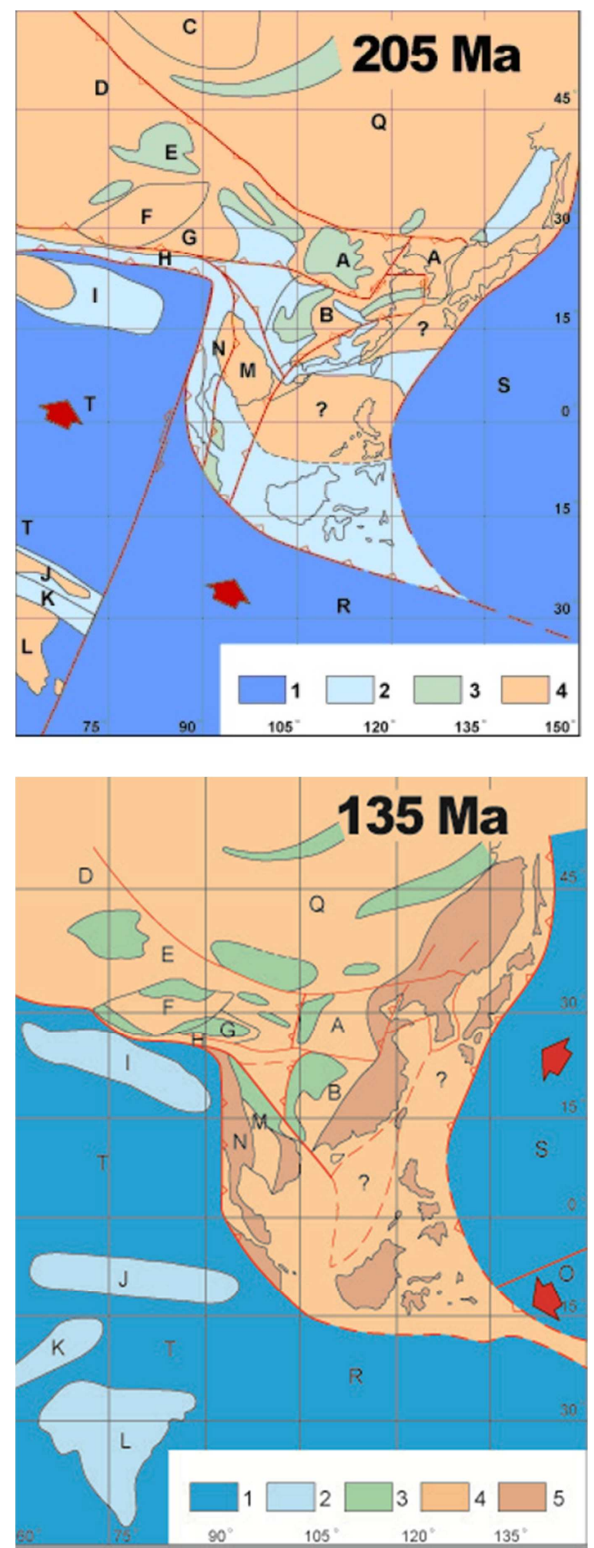

Fig. 8. Paleo-tectonogeographic reconstruction of China and adjacent blocks in the Triassic (205 Ma, U) and Jurassic (135 Ma, L) Periods. The paleomagnetic data are given in $[1,43]$.

Legend: 1, Ocean; 2, Sea, on continental shelf; 3, Continental sedimentary basin; 4, low land and hill; 5, Mountains.

The block symbols: A. Sino-Korean Plate; B. South China Plate (including Yangtze and Cathaysian plates); C. Siberian Plate; D. Kazakhstan Blocks; E. Junggar Block; F. Tarim Block; G. Qaidam Block; H. Kunlun Block; I. Qiangtang Block; J. Gandise Block; K. Himalayan Block; L. Indian Plate; M. Simao-Indosinian Plate; N. Baoshan-Sibumasu Plate; O. Pacific Plate; Q. Hingganling-Mongolia-Tianshan Collision Accretion Zone; R. Australian Plate; S. Izanagi Plate; T. Tethys Oceanic Plate. also the exhibition of counterclockwise rotation for Eastern Asian continent. 


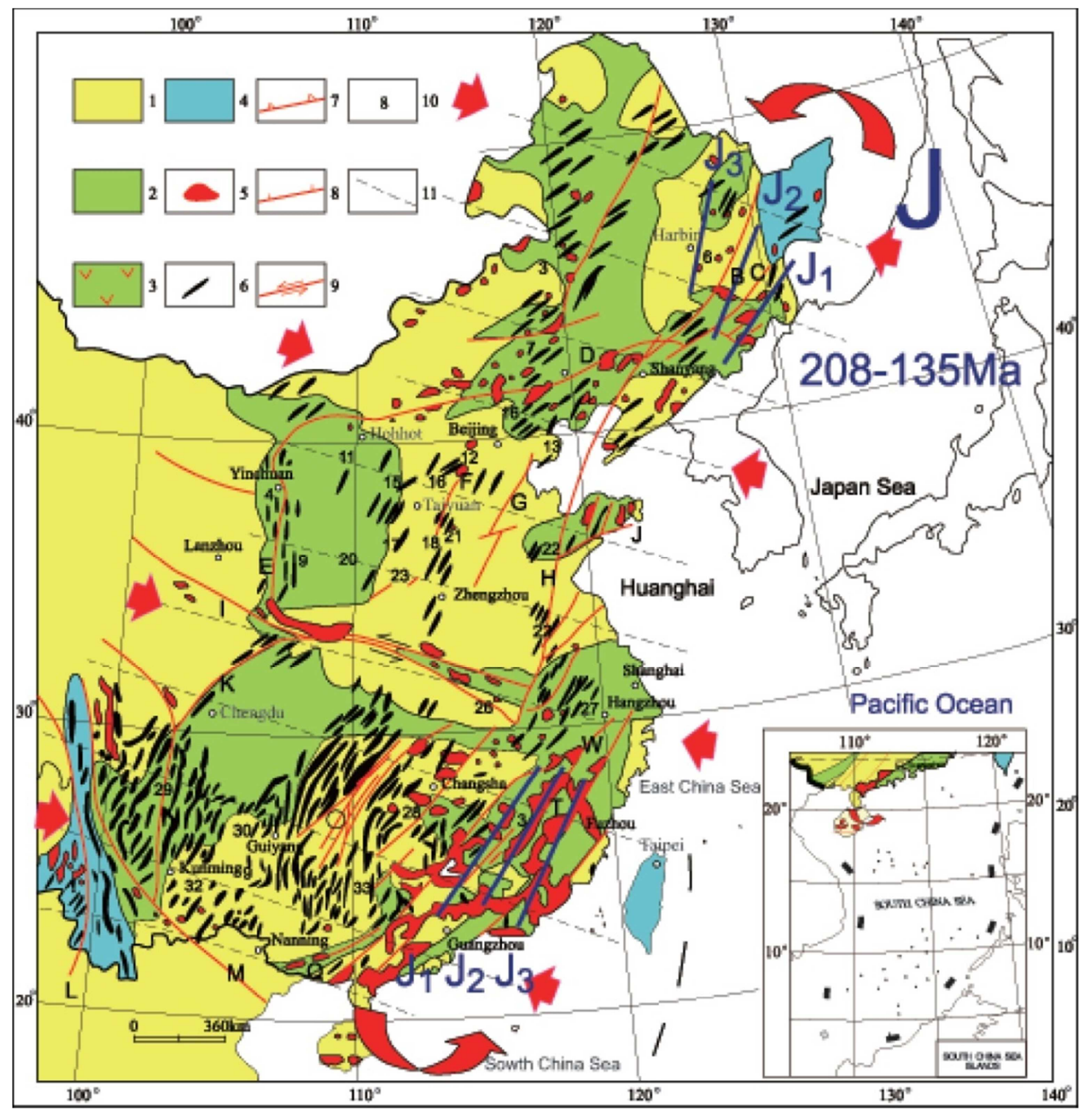

Fig. 9. Migration and rotation of tectono-magmatic zone in Jurassic [1].

J1, Early Jurassic magmatic zone; J2, Middle Jurassic magmatic zone, J3, Late Jurassic magmatic zone; Big red rotation arrow shows the rotation direction of tectono-magmatic zone.

Legend: 1, Jurassic Mountains; 2, basin; 3, volcanic rock; 4, shallow sea; 5, granite; 6, fold axes, anticlines are shown only; 7, reverse fault or thrust belts; 8 , normal fault; 9 , strike-slip fault; 10, number of area (here never shows the detail); 11, trace of maximum principal compressive stress $(\sigma 1)$ with small red arrow.

The magmatism of the Yanshanian Period was also extremely active in the Yanshan-west Liaoning-Taihangshan areas of North China (near Beijing). The tectono-magmatism zone from the Early, Middle to Late Jurassic also showed counter clockwise rotation, i. e. from ENE, NE to NNE trending, however the migration of those were not very clear, which may be connected with near the centre of crust rotation [1]. Thus, the authors inferred that the above counter clockwise rotation of tectono-magmatism zone during Jurassic is caused by the intersections among crustal faults, detachments of Mohorovìcìc discontinuity and middle crust, occurred by the forward propagation overthrust gradually.

It is well known that the thickness of continental lithosphere is $100-180 \mathrm{~km}$ commonly, and that of lithosphere with the continental crust and oceanic lithosphere mantle type is only $70-80 \mathrm{~km}$. The temperature at lithosphere bottom or top of asthenosphere is usually about $1210^{\circ} \mathrm{C}$, so in the thinner lithosphere, more heat will be transferred into crust, and the geothermal gradient should be increased obviously, thus it will be made a good condition to form magmatism. When formed the faults in crust at eastern Asian, it could be to cause partially decrease pressure and increase temperature in the relative close condition, thus easy to form magmatic source, caused magma intrusion upward and occurred magmatic zone. The temperature near middle crust is often about $600-700^{\circ} \mathrm{C}$, the condition of decrease pressure and increase temperature, reduced by tectonic activity is easy to form magma source for $\mathrm{S}$ or A type granite. So the thin lithosphere and faulting are two important factors to form stronger magmatism in Eastern China lithosphere. According to the original depths of magmatism are mainly at the middle crust and Mohorovicìc discontinuity, and only a few at the bottom of lithosphere [1].

So the authors considered that the detachment and rotation are mainly at middle crust, secondary at Mohorovìcìc 
discontinuity and very weak at the bottom of lithosphere in Eastern China lithosphere, but not the migration and rotation for whole continental lithosphere.

As to west to the line of Hingganling - Middle Shanxi-west ern Hubei - western Hunan-Eastern Yunnan and Eastern Thailand areas, there occurred many faults in crust really, however it is hardly to form strong magmatism. The reason is that there is typical continental lithosphere with rather huge thickness, geothermal gradient is so lower, and thus it is unfavorable to form the magma source.

As showed in former, the petrologists and geochemists [27, $39,40,44]$ recognized that the lithosphere mantle and asthenosphere underneath the Eastern Asia are no or weak disturbance and many weak disturbances all happened in Archaean or Proterozoic, never found any evidences for great disturbance in lithosphere mantle during Mesozoic and Cenozoic. As a result, the oceanic lithosphere mantle, beneath the Eastern Asia continental crust, should be the old, weak activity and relative stable tectonically, but not the hot, low density and strong activity. It is obviously unsuitable to explain the oceanic crust or oceanic lithosphere mantle caused by subduction of Pacific oceanic crust and mantle in Eastern China. According to the data of geophysical exploration (Fig. 6 ), the oceanic crust and mantle east to Asian continent subduction underneath the Eastern China continent about $500-600 \mathrm{~km}$ depth $[21,51,55,56]$, it has not any evidences to show the oceanic crust could be subducted to near earth surface, which depth is only several tens kilometers underneath the continental crust and more than one thousand kilometers distance near surface from oceanic trench and subduction zone.

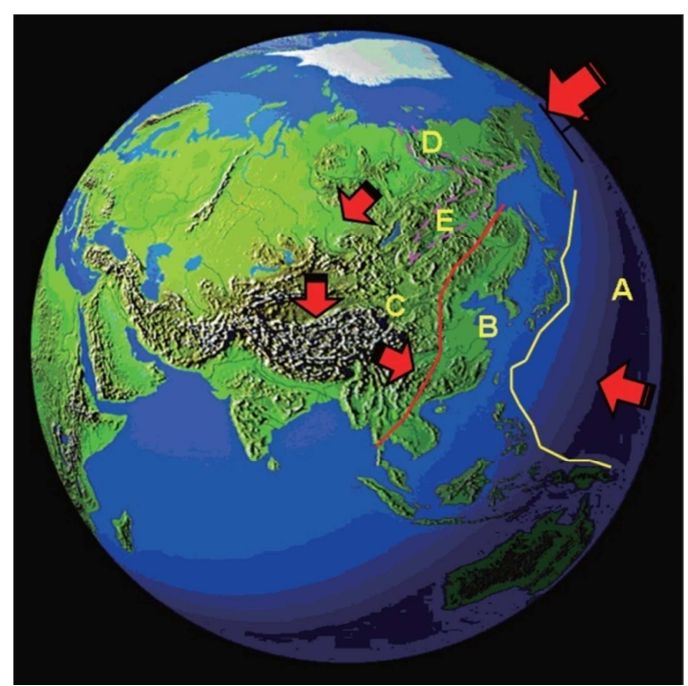

Fig. 10. Distribution and mechanism of Eastern Asian lithosphere with continental crust and oceanic lithosphere mantle during Jurassic.

Big and red arrow shows the compression and migration trending of North American Plate; other red arrows show the migration orientation of blocks, and exhibited the counterclockwise rotation for Eastern Asian continent.

A, Izanagi oceanic lithosphere plate; B, Eastern Asian lithosphere with continental crust and oceanic lithosphere mantle type; C, Asian continental lithosphere; D, Verkhojansk - Chersky Jurassic Collision Accretion Zone; E, Trans-Baikalia (or Mongolia-Okhotsk) Jurassic Collision Accretion Zone.
The above is the author's recognition for the special lithosphere type of Eastern China or Eastern Asia, it means that Eastern China lithosphere was a common continental lithosphere before Jurassic, however when in Jurassic Period the continental crust migrated onto the old oceanic mantle, and transformed to a new lithosphere type with continental crust and oceanic mantle (Fig. 7 and 10). This recognition is different to common plate tectonic theory, in which only emphasize the main detachment of lithosphere bottom and asthenosphere. In fact of continental tectonic research, it is considered earlier that the detachments and faults could be occurred between the sedimentary system and crystalline basement, middle crust or Mohorovìcìc discontinuity in the lithosphere [1, 25, 35, 84]. In former, it is not paid attention to the great detachment in continental crust with several hundreds kilometers. Now look to be, it is possible to happen the continental crust rotation and migration onto oceanic crust and lithosphere mantle.

As to the mechanism of lithosphere type transformation in Eastern Asian, the authors inferred that could be related by the WSW wards compression and collision of North American Plate [1] (Fig. 10), caused the extremely strong collisions at east and southeast borders of Siberian Plate, formed the Verkhojansk - Chersky Jurassic Collision Zone [85, 86] and Trans-Baikalia Jurassic Collision Zone [87] (H and I of Fig. 7; $\mathrm{D}$ and $\mathrm{E}$ of Fig. 10). Thus, in same time, it is to form the counter clockwise rotation of Eastern Asian continental crust [1], occurred partial continental crust migrated onto the old oceanic crust and lithosphere mantle, to form the special and thinner (about 70-80 km thickness) lithosphere with continental crust and oceanic mantle, and a wildish of several hundreds kilometers (B in Fig. 10). In same period the Izanagi oceanic lithosphere plate migrated to WNW trending and subducted underneath to the Asian continental lithosphere [88], which may be a certain resistance for eastwards migration of Eastern Asian continental crust.

Thus, it can be recognized that the lithosphere plates on the Earth are so different, they are not all the rigidity. However the rigidity plate was called in the preliminary period of plate tectonics theory, fifty years ago. Now it can be found that many plates had the rather strong intraplate deformations and detachments, which distribution areas could be more than several thousand kilometers wide, especially in the Asian continental plate. The important detachments near horizontal for the Eastern Asia continental plate were mainly rotation at the Mohorovìcic discontinuity and the middle crust in the Jurassic Period, but not only at the bottom of lithosphere. So the most of origin depths for Chinese strong earthquakes are concentrated near the Mohorovìcic discontinuity and the middle crust in recent.

To sum up, the authors proposed a new knowledge for lithosphere type transformation in Eastern China, just to offer a few common remarks for introduction, so that others may come up with valuable opinions, thus to promote development of the theory for China continental tectonics and global plate tectonics. 


\section{Acknowledgement}

This work was supported by geological survey project of The China Bureau of Geological Survey, No. Ke [2011] 01-48-11. The work has benefited greatly from discussion and collaborations with many geoscientists, with special thanks to Academician Zhao Wenjin and Zhai Mingguo, Professor Lu Fengxiang, Liu Deliang, Xiao Wenjiao, Yu Xinqi, and Wang Yu. Their important and precious recommendations are great helpful to correct the mistakes in manuscript and to more clearly explain the data and viewpoints.

\section{References}

[1] WAN Tianfeng, The Tectonics of China: Data, Maps and Evolution. Beijing, Heidelberg, Dordrecht, London, New York, Higher Education Press and Springer. 2011. pp. 1-501.

[2] HUANG, T. K. (J. Q.), On the Major Structural Forms of China. Geological Memoirs, 1945. Ser. A, No. 20, 1-165.

[3] HUANG, J. Q., Xiao, X. C., Ren, J. S., Basic Features of Tectonics of China - Specialties for One Three million Tectonic Map of China (in Chinese). Beijing: Industry Publishing House of China, 1964. 1-333.

[4] CHEN, G. D., The Activation of Platforms and Their Significances in Deposits - Investigation (in Chinese). Beijing Geological Publishing House. 1960, pp. 1-408.

[5] CHEN, G. D., (eds.), Crustobody Geotectonics of Asian Continent and Adjacent Seas (in Chinese). Changsha Education Publishing House of Hunan. 1998. pp. 1-322.

[6] REN, J. S., Jiang, C. F., Zhang, Z. K., The Geotectonic Evolution of China (in Chinese). Beijing, Science Press. 1980. pp. 1-124.

[7] REN, J. S., Chen, T. Y., Niu, B. G., Tectonic Evolution of the Continental Lithosphere and Metallogeny in Eastern China and Adjacent Areas (in Chinese). Beijing, Science Press. 1990. pp. $1-205$.

[8] REN, J. S., Wang, Z. X., Chen, B. W., China Tectonics, Outlooked by the Globe - Brief Direction of Tectonic Map of China and its Adjacent Areas. Beijing, Geological Publishing House. 2000. pp. 1-50.

[9] MA, X. Y., You, Z. D., Tan, Y. J., Some basic problems of China tectonics (in Chinese). Acta Geologica Sinica, 1961. 41(1), 30-44.

[10] Group of Regional Geology, Beijing College of Geology, Regional Geology in China (in Chinese). Beijing, Industry Publishing House of China, 1963. 1-404.

[11] GE, X. H., The formation history of intraplate orogenic belts in the north China paleo-plate (in Chinese with English abstract). Geological Review, 1989. 35 (3), 254-261.

[12] ZHAO, Z. P., An intracontinental-type orogeny - evidence from Qinling-Dabie orogenic belt, China (in Chinese with English abstract). Scientia Geologica Sinica, 1995. 30 (1), 19-28.

[13] CUI, S. Q., On global Meso-Cenozoic intracon-nental orogenesis and orogenic belts (in Chinese with English abstract). Earth Science Frontiers, 1999. 6 (4), 283-293.
[14] SONG, H. L., Characteristic of the Yanshan type intraplate orogenic belts and a discussion on its dynamics (in Chinese with English abstract). Earth Science Frontiers, 1999. 6 (4), 309-316.

[15] ZHANG, C. H., A primary discussion on the intraplate orogenic belt (in Chinese with English abstract). Earth Science Frontiers, 1999. 6 (4), 295-308.

[16] WU, F. Y., Xu, Y. G., Gao, S., The main controversy of North China lithosphere thinning and craton destruction (in Chinese). Acta Petrologica Sinica, 2008. 24, 1145-1174.

[17] ZHU, G., Hu, Z. Q., Chen, Y., The evolution of extension basin to indicate craton destruction of Early Cretaceous in eastern North China Craton. (in Chinese with English Abstract). Geology Bulletin, 2008. 27, 1594-1604.

[18] CHEN, Y., Zhu, G., Hu, Z. Q., The time and space change of Cretaceous-Paleogene tectonic subsidence and relationship of craton destruction in eastern North China (in Chinese). Geologica Scientia Sinica, 2009. 44, 836-854.

[19] XU, Y. G., Li, H. Y., Pang, C. J., On the time of destruction for North China Craton (in Chinese). Chinese Science Bulletin, 2009. 54: 1974-1989.

[20] ZHANG, J. J., Zheng, Y. F., Zhao, Z. F., Geochemical evidence for interaction between oceanic crust and lithospheric mantle in the origin of Cenozoic continental basalts in east-central China. Lithos, 2009. 110, 305-326.

[21] ZHU, R. X., Zheng, T. Y., Destruction mechanism of North China Craton and Paleoproterozoic plate tectonic system (in Chinese). Chinese Science Bulletin, 2009. 54, 1950-1961.

[22] ZHU, R. X., Chen, L., Wu, F. Y., The time, limits and destruction mechanism of North China Craton (in Chinese). Science China, D (Earth Sciences), 2011. 41, 583-592.

[23] MELCHER, F., Meisel, T., Puhl, J. Petrogenesis and geotectonic setting of ultramafic rocks in the Eastern Alps: constraints from geochemistry. Lithos, 2002. 65 (1-2), 69-112.

[24] MENZIES, M. A., Fan, W. M., Zhang, M., Paleozoic and Cenozoic lithoprobes and the loss of $>120 \mathrm{~km}$ of Archean lithosphere Sino- Korean craton, China. In Prichard, H. M. (ed.), Magmatic and plate tectonics. Geological Society Special Publication. 1993. 76, pp. 71-81.

[25] WAN, T. F., Zhu, H., Zhao, L., Formation and Evolution of the Tancheng - Lujiang Fault Zone. Wuhan, Press of China University of Geosciences, 1996. pp. 1-85.

[26] CAI, X. L., Zhu, J. S., Cao, J. M., Structure and dynamics of lithosphere and asthenosphere in the gigantic East Asian - West Pacific rift system (in Chinese with English Abstract). Geology in China, 2002. 29 (3), 234-245.

[27] LU, F. X., Wu, Q. F. et al., Composition, structure and sphere interaction of lower lithosphere in typical area of Eastern China (in Chinese). Wuhan, China University of Geosciences Press. 2005. pp. 1-195.

[28] WAN, T. F., Wang, Y. M., Liu, J. L., Detachment and magmatic source depth in lithosphere of Eastern China during Yanshanian and Sichuanian stages (in Chinese with English Abstract). Earth Science Frontiers, 2008. 15 (3), 1-35.

[29] LI, T. D., The Principal characteristics of the lithosphere of China. Geoscience Frontiers, 2010. (1), 45-50. 
[30] YIN, X. H., Liu, Z P., Wu, J. X., The features of bouguer gravity field and structures of crust-upper mantle in the transition zone on the eastern border of Qinghai-Xizang-Mongolian Plateau (in Chinese with English Abstract). Seismology and Geology, 1988. 10 (4), 143-150.

[31] WENG, W. H., Crustal movements and volcanic activities of east China since Mesozoic. Journal of Geological Society of China, 1927. 6 (1), 9-36.

[32] WAN, T. F., Intraplate Deformation, Tectonic Stress Field and their Application for Eastern China in Meso-Cenozoic. Wuhan, Press of China. University of Geosciences. 1994. pp. 1-156.

[33] ZHAI, M. G., Zhu, R. X., Liu, J. M., Key period of tectonic system transformation of Eastern North China in Mesozoic (in Chinese). Science in China, D Erath Sciences, 2003. 33, 913-930.

[34] CHEN, Y. Q. (Chief editor), Introduction to China Regional Geology (in Chinese). Beijing Geological Publishing House. 1994. pp. 1-517.

[35] WAN, T. F. and Zhao, Q. L., The genesis of tectono-magmatism in eastern China. Science China, Earth Sciences, 2012. 55 (3), 347-354.

[36] LI, C. Y., Sichuan movement and its distribution in China. Journal of Geological Society of China, 1950. 30, 1-8.

[37] WANG, Y. M. and Wan, T. F., Lithosphere Tectonic Detachments in Eastern China Control of Cenozoic Magmatism and Earthquake (in Chinese with English abstract). Geoscience, 2008. 22(2), 207-229.

[38] LU, F. X., Wu, Q. F. et al., Composition, structure and sphere interaction of lower lithosphere in typical area of Eastern China (in Chinese). Wuhan, China University of Geosciences Press. 2005. pp. 1-195.

[39] LU, F. X., Zheng, J. P., Shao, J. A. et al., Asthenospheric upwelling and lithospheric thinning in Late Cretaceous Cenozoic in eastern North China (in Chinese with English abstract). Earth Science Frontiers, 2006. 13(2), 86-92.

[40] LU, F. X., Multiple geological events of old lithosphere mantle in North China Craton: From inspiration of peridotite xenolith in kimberlite (in Chinese with English abstract). Acta Petrology, 2010. 26(11), 3177-3188.

[41] ZHOU, X. H., Major transformation of subconinenal lithosphere beneath eastern China in the Cenozoic- Mesozoic: review and prospect (in Chinese with English abstract). Earth Science Frontiers, 2006. 13(2), 50-64.

[42] ZHANG, H. F., Yang, Y. H., Santosh, M., Evolution of the Archean and Paleoproterozoic lower crust beneath the Trans-North China Orogen and the Western Block of the North China Craton. Gondwana Res. 2012., doi: 10.1016/j.gr.2011.1008.1011.

[43] WAN, T. F. and Zhu, H., Chinese Continental Blocks in Global Paleocontinental Reconstructions during the Paleozoic and Mesozoic. Acta Geologica Sinica, 2011. 85 (3), 581-597.

[44] ZHOU, X. H., Major transformation of subcontinental lithosphere beneath eastern China in the Cenozoic- Mesozoic: review and prospect (in Chinese with English abstract). Earth Science Frontiers, 2006. 13(2), 50-64.
[45] ZHANG, J. S., Xu, J., Wan, J. L., Meso-Cenozoic detachment zones in the front of the Taihang Mountains and their fission-track ages (in Chinese with English Abstract). Geological Bulletin of China, 2002. 21 (4-5), 207-210.

[46] WU, F. Y., Ge, W. T., Sun, D. Y., Discussions on the lithospheric thinning in Eastern China. (in Chinese with English abstract). Earth Sciences Frontiers, 2003. 10(3), 51-60.

[47] WU, F. Y., Xu, Y. G., Gao, S., The main controversy of North China lithosphere thinning and craton destruction (in Chinese). Acta Petrologica Sinica, 2008. 24, 1145-1174.

[48] ZHU, R. X., Chen, L., Wu, F. Y., The time, limits and destruction mechanism of North China Craton (in Chinese). Science China, D Earth Sciences, 2011. 41, 583-592.

[49] ZHANG, J. J., Zheng, Y. F., Zhao, Z. F., Geochemical evidence for interaction between oceanic crust and lithospheric mantle in the origin of Cenozoic continental basalts in east-central China. Lithos, 2009. 110, 305-326.

[50] XU, Y. G., Li, H. Y., Pang, C. J., On the time of destruction for North China Craton (in Chinese). Chinese Science Bulletin, 2009. 54: 1974-1989.

[51] ZHENG, T. Y., Zhao, L., Zhu, R. X., New evidence from seismic imaging for subduction during assembly of the North China craton. Geology, 2009. 37, 395-398.

[52] QING, J. X., Hao, T. Y., Xu, Y., The depth distribution of Moho discontinuity and relationship to tectonic units in South China Sea and adjacent areas (in Chinese with English abstract). Acta Geophysica Sinica, 54, 2011. (12), 3171-3183.

[53] YU, S. Y., Xu, Y. G., Ma, J. L., Remnants of oceanic lower crust in the subcontinental lithospheric mantle: Trace element and $\mathrm{Sr}-\mathrm{Nd}-\mathrm{O}$ isotope evidence from aluminous garnet pyroxenite xenoliths from Jiaohe, Northeast China. Earth Planet Science Letter, 2010. 297, 413-422.

[54] GAO, S, Rudnick, R. L., Xu, W. L., Recycling deep cratonic lithosphere and generation of intraplate magmatism in North China Craton. Earth Planet Science Letter, 2008. 270, 41-53.

[55] ZHAO, D. P., Global tomographic images of mantle plumes and subducting slabs insight into deep Earth dynamics. Physics of the Earth and Planetary Interiors, 2004. 146, 3-34.

[56] ZHAO, D. P. and Liu, L., Deep structure and origin of active volcanoes in China. Geoscience Frontiers, 2010. 1(1), 31-44.

[57] ZHU, G., Hu, Z. Q., Chen, Y., The evolution of extension basin to indicate craton destruction of Early Cretaceous in eastern North China Craton. (in Chinese with English Abstract) Geology Bulletin, 2008. 27, 1594-1604.

[58] ZHANG, H. F., Interaction of peridotite-melt: The key of been destructed for lithosphere mantle with craton type (in Chinese) Chinese Science Bulletin, 2009. 54, 2008-2026.

[59] AMES, L., Tilton, G. R., Zhou, G., Timing of collision of the Sino-Korean and Yangtze cratons: U-Pb zircon dating of coesite-bearing eclogites. Geology 1993. 21, 339-342.

[60] MARUYAMA, S., Liou, J. G., Zhang, R., Tectonic evolution of the ultrahigh-pressure (UHP) and high-pressure (HP) metamorphic belts from central China. The Island Arc, 1992. 3 (2): $112-121$. 
[61] CONG, B. L. and Wang, Q. C., Ultra-high-pressure metamorphic rocks in China. Episodes, 1995. 18 (1-2), 91-94.

[62] CONG, B. L. and Wang, Q. C., The Dabie-Sulu UHP rocks belt: review and prospect. Chinese Science Bulletin, 1999. 44 (12), 1074-1086.

[63] LI, S. G., Jagoutz, E., Xiao, Y. L. et al., Ultrahigh pressure metamorphic chronology in Dabieshan - Sulu terrane - I. Sm-Nd isotopic system (in Chinese). Science in China, 1996. D 26 (3), 249-257.

[64] LI, S. G., Li, H. M., Chen, Y. Z. et al., Ultrahigh pressure metamorphic chronology in Dabieshan - Sulu terrane - II. zircon U-Pb isotopic system (in Chinese). Science in China, 1997. D 27 (3), 200-206.

[65] WEBB, L. E., Hacker, B. R., Ratschbacher, L., Thermo-chronologic constraints on deformation and cooling history of high - and ultrahigh-pressure rocks in the Qinling-Dabie orogen, eastern China. Tectonics, 1999. 18 (4), 621-638.

[66] LIU, Y. C., Xu, S. T., Li, S. G. et al., Tectonic setting and cooling history of eclogites from Northern Dabie Mountains (in Chinese with English Abstract). Earth Science, 2003. 28 (1). 11-16.

[67] ZHANG, G. W., Zhang, B. R., Yuan, X. C., Qinling Orogenic Belt and Continental Dynamics (in Chinese). Beijing, Science Press, 2001. pp. 1-855.

[68] SUO, S. T., Zhong, Z. Q., You, Z. D., Relic UHP structures in Dabie-Sulu region, China: structures expression and geodynamic significance (in Chinese with English Abstract). Earth Science, 2000. 25 (6), 557-563.

[69] LIN, J. L., Fuller, M., Zhang, W. Y., Preliminary Phanerozoic polar wander paths for the North and South China blocks. Nature, 1985. 313, 444-449.

[70] FANG, D. J., Guo, Y. B., Wang, Z. L. et al., Tectonic significance of paleomagnetic study on the Triassic and Jurassic systems in Ningwu basin, Shanxi. Chinese Science Bulletin, 1988. 33 (24), 2057-2059.

[71] MA, X. H., Yang, Z. Y., The collision and suturing of the three major blocks in China and the reconstruction of the Paleo-Eurasian continent (in Chinese with English Abstract). Acta Geophysica Sinica, 1993. 36 (4): 476-488.

[72] ZHAO, X. X., Coe, R. S, Plate tectonics, China. Gubbins D. and Herrero-Bervera E. eds., Encyclopedia of Geomagnetism and Paleomagnetism, Part 16, Dordrecht, Springer. 2007. pp. 816-828.

[73] HUANG, B. C.,Zhou, Y. X.,Zhu, R. X.,Discussion on Phanerozoic evolution and formation of continent China: Based on paleomagnetic studies (in Chinese with English abstract). Earth Science Frontiers, 2008. 15(3), 348-359.

[74] HUANG, B. C., Zhu, R. X., Yang, Z. Y., Study of Paleozoic kinematics features of the North China block (in Chinese with English Abstract). Geoscience, 1999. 13 (suppl.), 1-7.

[75] KIM K. H., Van der Voo, R., Jurassic and Triassic paleomagnetism of South Korea. Tectonics, 1990. 9 (4), 699-717.
[76] ZHU Z. W., Hao, T. Y., Zhao, H. S., Paleomagnetism and its implication of Pan-Xi region in Mesozoic. In: Zhang, Y. X., Yuan, X. C. (eds.), Collection of Pan-Xi Rift, China (in Chinese with English abstract), Beijing: Geological Publishing House, 3, 1988. pp. 199-211.

[77] LIANG Q. Z., Paleo-magnetic Research on Petrological Phase Paleogeography and Sedimentation (in Chinese). Institute of Scientific Research, Geological Bureau of Yunnan, 1990. 1-106.

[78] HUANG, K. N. and Opdyke, N. D., Paleomagnetic results from Cretaceous and Jurassic rocks of South and Southwest Yunnan: evidence for large clockwise rotations in the Indochina and Shan-Thai-Malay terranes. Earth Planet Science Letter, 1993. $117,507-524$.

[79] ENKIN, R. J., Yang, Z. Y., Chen, Y., Courtilot, V., Paleomagnetic constrains on the geodynamic history of the major blocks of China from the Permian to the present. Journal of Geophysical Research, 1992. 97, 13 953-13 989.

[80] KHRAMOV, A. N., Petrova, G. N., Peckersky, D. M., Paleomagnetism of Soviet Union. In McElhinny, M. W., Valencio, D. A. eds., Paleoconstruction of the Continents, Geodynamic Series. Boulder, Colorado, Geological Society of America, 1981. pp. 177-194.

[81] XU, W. L., Ge, W. C., Pei, F. P. et al., Chronology of Mesozoic volcanism and its tectonic significance in Northeast China (in Chinese). Proceedings of China Mineralogy, Petrology and Geochemistry Conference. Guiyang, 2009. pp. 105.

[82] ZHAN, M. G., Research on Mesozoic Tectono - Magmatism - Metallogeny and Regional Minerallization of South China. (in Chinese with English abstract). Ph D thesis of China University of Geosciences, 1994. pp. 1-203.

[83] ZENG, H. L., Liu, J., Zhang, Q. H., Gravity and magnetic data processing and interpretation and its application to research on crustal structure. 1994 Annual Report, The Laboratory of Lithosphere tectonics and its Dynamics (MGMR). Beijing: Seismological Press. 1995. pp. 87-101.

[84] ZHANG, W. Y., An Introduction to Fault-Block Tectonics (in Chinese). Beijing, Petroleum Industry Press. 1984. pp. 1-385.

[85] OXMAN, V. S., Tectonic evolution of the Mesozoic Verkhoyansk - Kolyma belt (NE Asia). Tectonophysics, 2003. 365 (1-4), 45-76.

[86] PETROV, O. (editor in chief), Tectonic Zoning of Central Asia and Adjacent Areas (1: 20000 000). In: Atlas of Geological Maps of Central Asia and Adjacent areas (1: 2500 000). VSEGEI Cartographic Factory. 2008.

[87] ZOLIN, Y. A., Zorina, L. D., Spiridonov, A. M., Geodynamic setting of gold deposits in Eastern and Central Trans- Baikal (Chita Region, Russia). Ore Geology Reviews, 2001. 17, 215-232.

[88] MOORE, G. W., Mesozoic and Cenozoic paleo-geographic development of the Pacific region. Abstract, $28^{\text {th }}$ International Geological Congress, Washington D C, USA. 1989. pp. 2 455-456. 